\title{
HIV and AIDS knowledge of Pharmacy students at the University of Limpopo (Medunsa Campus)/Tshwane University of Technology before and after a teaching intervention
}

\author{
S BeZUidenHout AND RS SUMmers*
}

\begin{abstract}
Healthcare workers need to be qualified to deal with the specific requirements of the HIV/AIDS syndrome, which demands technical and scientific knowledge and understanding of the disease. Adequate knowledge about HIV/AIDS is an important means to reduce stress and could result in better care and improve information to the general public. Because of the community service nature of pharmacies, pharmacists are in the front line when it comes to treating minor illnesses, as patients will often approach a pharmacist with a health query before they see a medical practitioner. Hence, pharmacists have opportunities to recognise potential opportunistic infections or other HIV-associated complications and to refer patients for evaluation and management.

The objective of this study was to assess the level of scientific knowledge of HIV/AIDS of undergraduate pharmacy students before and after a teaching intervention aimed to improve students' scientific knowledge of the subject. A controlled study was carried out by administering pre- and post-intervention questionnaires to control and study groups. The study group was taken from the various BPharm student groups during 2004 and 2005. Although each group acted as its own control, an additional control group of first year dentistry students was included in 2005. The mean HIV/AIDS knowledge scores and the knowledge gains of the control and study groups were compared before and after the intervention. The knowledge gains from the interventions were statistically significant. The increases indicate the positive effect of the teaching intervention. The teaching intervention can therefore be recommended to be part of the undergraduate BPharm curriculum.
\end{abstract}

Keywords: HIV/AIDS, pharmacists, knowledge, education, intervention

Disciplines: Health studies, Sociology, Education

\section{Introduction}

From its beginning, the HIV/AIDS epidemic has been accompanied by a climate of fear, ignorance and denial, leading to stigmatisation of and discrimination against people with HIV/AIDS. Ignorance and fear underlie HIV-related stigma. An inadequate understanding of the modes of HIV transmission causes fear of transmission from casual contact

* Dr Selente Bezuidenhout and Prof. Richard Summers are attached to the School of Pharmacy. University of Limpopo (Medunsa Campus). 
(Letamo, 2004). Fear of contagion and fear of death have clear negative effects on health care workers' attitudes toward and treatment of HIVpositive patients. HIV/AIDS has generated concern, fear, anxiety and prejudice among both health care personnel and the general public (Prasad, 2001). The knowledge and attitudes of health care personnel regarding HIV/AIDS comprise an important dimension in the delivery of quality care to persons living with HIV/AIDS (ASHP Statement, 1993).

With no cure for HIV and a safe and effective vaccine several years away, the number of cases will increase well into the $21^{\text {st }}$ Century. Additionally, the decrease in opportunistic infections brought about by highly active antiretroviral therapy (HAART) means that the care of patients infected with HIV will be largely transferred to the outpatient setting (Cantwell-Mcnelis \& James, 2002).

By far the most significant component of any health system is its health personnel. Without a foundation of skilled human resources, health care systems cannot function adequately or effectively, particularly in the public sector and at the primary level of care. Given that health workers are expected to provide care and accurate information on this subject matter to patients and their relatives, as well as to the general public, it is clearly important that they have credible and accurate knowledge of the disease (Umeh et al, 2008). This need applies particularly to pharmacists because of the community service nature of pharmacies, where pharmacists are in the front line when it comes to treating minor illnesses. Patients often approach a pharmacist with a health query before they see a medical practitioner. Pharmacists should therefore have the ability to recognise potential opportunistic infections or other HIV-associated complications and refer patients appropriately for evaluation and management.

The magnitude of the HIV/AIDS epidemic has increased demands on pharmacists and other health care workers. Specific knowledge and skills are required to counsel and advise patients on HIV prevention and treatment (Myers, et al, 1998).

During 1994, Sheridan and colleagues found that pharmacy students at the University of London had a significantly increased knowledge of HIV/ AIDS after attending a series of lectures on the topic as part of their undergraduate course. In a study to explore pharmacy students' knowledge and beliefs about HIV/AIDS, Blumenthal and colleagues (2002) found that students would benefit from more time on HIV/AIDS topics, including AIDS treatment medication and prevention. Based on these findings educators need to examine approaches to teaching about HIV/ AIDS that can increase knowledge and influence the actual treatment of individuals who have this disease.

Additionally, graduates in health sciences must be equipped to meet the demands of their professional calling. Pharmaceutical educators must teach pharmaceutical care to students. Pharmacy curricula should be designed to produce graduates with sufficient knowledge and skills to provide pharmaceutical care competently, particularly for HIV/AIDS patients (ASHP Statement, 1993). In Africa, HIV/AIDS is most prevalent within the 15-24 year old age group (Santis, W. et al, 2003). There is a gap in programmes targeting youth of ages 18-24 years, for example those enrolled in tertiary education institutions (Cornelissen, 2005). 
From the above studies and others carried out to assess the knowledge of pharmacy students regarding HIV/AIDS it is evident that basic undergraduate training in this subject is essential. The pharmacist's role in AIDS patient care is likely to grow in the coming years as more AIDS patients live longer and receive treatment that is more consistent with chronic care.

As HIV/AIDS continues to spread and affect the lives of millions of people, a sense of urgency has developed about the imperative need to stop the epidemic. With an effective vaccine unlikely to be available for at least 10 years, prevention of transmission through education and behaviour change remains important to halt the epidemic's spread. The main behaviour change strategies available which aim to prevent HIV infection include raising awareness and educating people about the disease (Harrison et al, 2000). All over the world, national HIV/AIDS agencies, along with nongovernmental organisations and the media, have implemented programmes to expand the response to the epidemic.

The main goal of these efforts is to prevent the transmission of HIV (Fisher $\&$ Foreit, 2002). However, together with knowledge, behavioural change strategies are necessary to reduce HIV transmission and these strategies themselves need to be combinations of approaches at multiple levels of influence (Coates et al, 2008).

Having set a general picture we now look specifically at the country which has the largest number of individuals affected by AIDS in the world. South Africa is experiencing an explosive epidemic of HIV/AIDS and in 2003 the South African government approved and initiated a Comprehensive National Plan on HIV and AIDS Care, Management and Treatment, which aims, among other objectives, to provide access to antiretroviral treatment to more than 1.4 million South Africans by 2008 (www.cdc.gov - 26-01-2006). The plan will necessitate the pharmacist's involvement in the dispensing of treatment and the management of effective medicines' use. A trusting relationship between the pharmacist and the patient is essential. Hence, pharmacists should be at ease with the disease and have sufficient knowledge about HIV and its consequences.

As the knowledge and attitudes of health care workers regarding HIV/ AIDS still leave much to be desired, even after two decades of sustained effort, many health care workers still harbour a morbid fear of the disease (Bhatnagar \& Bhalwar, 2005). In this paper we focus, on the knowledge of pharmacy students about HIV and AIDS and to what extent the situation can be improved by a targeted short course.

\section{Aim}

To assess the baseline level of knowledge and understanding of HIV/ AIDS of undergraduate pharmacy students at the University of Limpopo (Medunsa Campus)/Tshwane University of Technology Schools of Pharmacy and to determine the effect of a teaching intervention aimed to improve students' knowledge on the subject.

\section{Method}




\subsection{Study design}

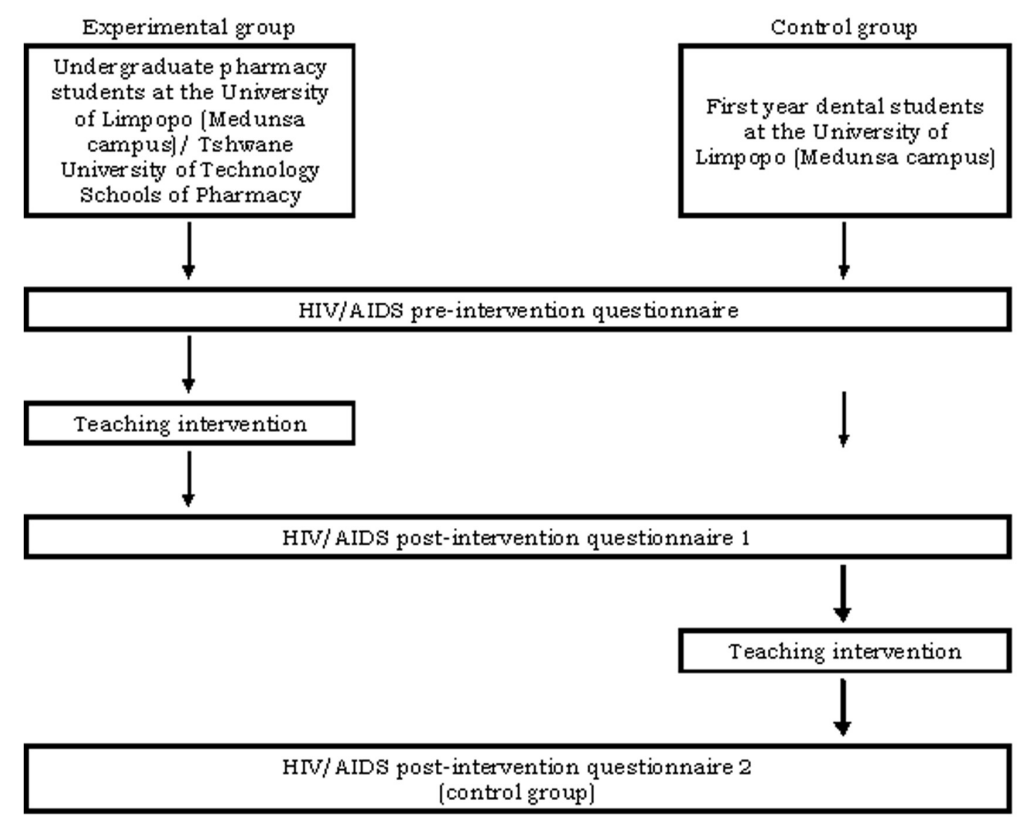

\subsection{Target population}

The target population consisted of all undergraduate pharmacy students (180) from the University of Limpopo (Medunsa Campus)/Tshwane University of Technology Schools of Pharmacy in 2004 and 2005.

All undergraduate pharmacy students in the respective years formed the study groups, with each group acting as its own control, due to the before-and-after nature of the experiment. First year dental students (53) from the University of Limpopo (Medunsa Campus) in 2005 were included as an additional, external control.

\subsection{Survey instrument}

A structured HIV knowledge questionnaire was designed specifically for this study to determine the level of knowledge and understanding of HIV/ AIDS of pharmacy students at the University of Limpopo (Medunsa Campus)/Tshwane University of Technology Schools of Pharmacy and to determine the effect of the teaching intervention. The questionnaire was administered to the study and control groups at the pre-test and post-test 1 stage. As a favour to the Dentistry Department the control group also completed the teaching intervention at a later stage after which post-test 2 questionnaires were administered to the control group. This questionnaire was designed in the true/false format and consisted of 40 questions.

\subsection{Ethicalapproval}

Ethical approval for the study was obtained from the Medunsa Research, 
Ethics and Publications Committee.

\subsection{Intervention (the teaching programme)}

The authors, other members of the University of Limpopo (Medunsa Campus) School of Pharmacy and some external experts compiled a teaching programme according to the FIP/WHO guidelines and layout as a continuing professional development (CPD) course for pharmacists (accredited by the South African Pharmacy Council). The course was then adapted for undergraduate teaching purposes by excluding certain topics (Drug supply and quality assurance was excluded due to time constraints). The teaching programme is available in printed format as well as in interactive format on a CD-ROM (School of Pharmacy, 2003).

The teaching programme was presented in a two and a half hour session. It consisted of eight modules, which covered the following aspects.

- General knowledge

- Transmission

- Antiretroviral treatment

- Diagnosis

- Counselling

- Signs and symptoms

- Opportunistic infections

- Post-exposure prophylaxis

- Palliative care

\subsection{Statistical analysis}

All statistical procedures were perform-a from the HIV/AIDS knowledge questionnaires were analysed for all groups. Differences between pretest, post-test 1 and post-test 2 scores for the control group and differences between pre-test and post-test 1 scores for the other study groups were analysed. A paired t-test was used for comparison of the mean pre and post-intervention scores within groups. Responses were paired per respondent so that each served as his/her own control and to reduce bias. Paired comparisons could only be conducted on subjects who completed both the pre- and post-assessment. In some comparisons this requirement resulted in a reduction of sample sizes.

Some other aspects of the data were also analysed: A Pearson correlation analysis was performed to determine whether there was a relationship between HIV/AIDS knowledge and age.

\subsection{Null hypothesis}

The knowledge of pharmacy students from the University of Limpopo (Medunsa Campus)/Tshwane University of Technology Schools of Pharmacy regarding HIV infection and AIDS will not improve after a 
teaching intervention.

\section{Results}

Changes in the HIV/AIDS knowledge scores from the pre-test to post-test 1 and post-test 2 were calculated for the control group. Subsequently, the changes from the pre-test to post-test 1 scores were calculated for the study groups. Changes from pre-test to post-test 1 and to post-test 2, where applicable, were converted to a scale where positive changes (improvements) were indicated by positive numbers and negative changes (deteriorations) were indicated by negative numbers. A zero value indicated no change.

Five groups of students (Control group, 1st year 2004, 1st year 2005, 3rd year 2005 and 4th year 2005) completed the HIV/AIDS Knowledge Questionnaire. The HIV Knowledge Questionnaire consisted of

- two questions on demographic characteristics (age and gender), and

- forty questions/statements in the true/false format.

Results of the pre-test, post-test 1 and post-test 2 for the control group were analysed. Subsequently, results of the pre-test and post-test 1 for the study groups were analysed. A paired t-test was used for comparison of mean pre and post-intervention scores. Results are presented in the form of tables followed by a short discussion.

\subsection{Composition of student groups}

Table 1: Age distribution of students

\begin{tabular}{|c|c|c|c|c|c|c|c|}
\hline \multicolumn{2}{|c|}{ Group } & $\begin{array}{c}\text { Number } \\
\text { of } \\
\text { students }\end{array}$ & $\begin{array}{l}\text { Response } \\
\text { rate }\end{array}$ & $<20$ years & $\begin{array}{l}20-22 \\
\text { years }\end{array}$ & $\begin{array}{l}23-25 \\
\text { years }\end{array}$ & $>25$ years \\
\hline \multicolumn{2}{|c|}{ Control group } & 53 & $52(98 \%)$ & $26(50 \%)$ & $15(29 \%)$ & $7(13 \%)$ & $4(8 \%)$ \\
\hline \multirow{4}{*}{$\begin{array}{l}\text { Study } \\
\text { groups }\end{array}$} & $\begin{array}{l}\text { 1st year } \\
2004\end{array}$ & 46 & $43(93 \%)$ & $23(54 \%)$ & $13(30 \%)$ & $1(2 \%)$ & $6(14 \%)$ \\
\hline & $\begin{array}{c}\text { 1st year } \\
2005\end{array}$ & 51 & $49(96 \%)$ & 19 (39\%) & $20(41 \%)$ & $3(6 \%)$ & $7(14 \%)$ \\
\hline & $\begin{array}{l}\text { 3rd year } \\
2005\end{array}$ & 38 & $37(97 \%)$ & $1(3 \%)$ & $20(54 \%)$ & $4(11 \%)$ & $12(32 \%)$ \\
\hline & $\begin{array}{l}\text { 4th year } \\
2005\end{array}$ & 45 & 43 (96\%) & $1(2 \%)$ & $23(54 \%)$ & $9(21 \%)$ & $10(23 \%)$ \\
\hline \multicolumn{2}{|c|}{$\begin{array}{c}\text { Sub-total of study } \\
\text { groups }\end{array}$} & 180 & $172(96 \%)$ & $44(26 \%)$ & $76(44 \%)$ & $17(10 \%)$ & $35(20 \%)$ \\
\hline \multicolumn{2}{|c|}{ Total } & 233 & $224(96 \%)$ & $70(31 \%)$ & $91(41 \%)$ & $24(11 \%)$ & $39(17 \%)$ \\
\hline
\end{tabular}


Table 2: Gender distribution of students

\begin{tabular}{|c|c|c|c|c|c|}
\hline \multicolumn{2}{|c|}{ Group } & $\begin{array}{c}\text { Number } \\
\text { of } \\
\text { students }\end{array}$ & $\begin{array}{c}\text { Response } \\
\text { rate }\end{array}$ & Male & Female \\
\hline \multirow{2}{*}{ Control group } & 53 & $52(98 \%)$ & $21(40 \%)$ & $31(60 \%)$ \\
\hline \multirow{2}{*}{$\begin{array}{c}\text { Study } \\
\text { groups }\end{array}$} & $\begin{array}{c}\mathbf{1 s t} \text { year } \\
\mathbf{2 0 0 5}\end{array}$ & 51 & $44(96 \%)$ & $10(23 \%)$ & $34(77 \%)$ \\
\cline { 2 - 6 } & $\begin{array}{c}\mathbf{3 r d} \text { year } \\
\mathbf{2 0 0 5}\end{array}$ & 38 & $36(95 \%)$ & $14(39 \%)$ & $26(54 \%)$ \\
\cline { 2 - 6 } & $\begin{array}{c}\mathbf{4 t h} \text { year } \\
\mathbf{2 0 0 5}\end{array}$ & 45 & $44(98 \%)$ & $8(18 \%)$ & $36(82 \%)$ \\
\hline \multicolumn{2}{|c|}{$\begin{array}{c}\text { Sub-total of study } \\
\text { groups }\end{array}$} & 180 & $172(96 \%)$ & $54(31 \%)$ & $118(69 \%)$ \\
\hline \multicolumn{2}{|r|}{ Tota1 } & $\mathbf{2 3 3}$ & $\mathbf{2 2 4}(\mathbf{9 6} \%)$ & $\mathbf{7 5}(\mathbf{3 3} \%)$ & $\mathbf{1 4 9}(\mathbf{6 7} \%)$ \\
\hline
\end{tabular}

4.2 Comparison of percentage knowledge scores in the various age categories at pre-test, post-test 1 and post-test 2

Students from the control group did not receive an intervention between the pre and post 1 questionnaire. Only after data were collected from the pre- and post-1 questionnaires did they receive the intervention.

Table 3: Mean percentage knowledge scores in the various age categories: controlgroup

\begin{tabular}{|c|c|c|c|c|c|c|c|}
\hline Age & Number & $\begin{array}{c}\text { Pre- } \\
\text { test }\end{array}$ & Post 1 & Post 2 & $\begin{array}{c}\text { Difference } \\
\text { pre-post 1 }\end{array}$ & $\begin{array}{c}\text { Difference } \\
\text { pre-post 2 }\end{array}$ & $\begin{array}{c}\text { p-value } \\
\text { (pre-post 2) }\end{array}$ \\
\hline$<20$ & 26 & 41.73 & 42.69 & 70.48 & 0.96 & 28.75 & $<0.0001^{* * *}$ \\
\hline $\mathbf{2 0 - 2 2}$ & 15 & 49.17 & 49.00 & 75.33 & -0.17 & 26.16 & $<0.0001^{* * *}$ \\
\hline $\mathbf{2 3 - 2 5}$ & 7 & 58.57 & 52.50 & 71.79 & -6.07 & 13.22 & $0.0044^{* *}$ \\
\hline$>\mathbf{2 5}$ & 4 & 50.63 & 48.75 & 75.63 & -1.88 & 25.00 & $0.0114^{* *}$ \\
\hline
\end{tabular}

*** Statistically very highly significant, paired t-test. $p<0.0001$

** Statistically highly significant, paired t-test. $p<0.01$

\section{Data}

The differences found in the control group at post-test 1, compared with pre test, were not significant in any of the age groups, or in the control group as a whole. This means that the changes observed in knowledge scores can be assumed to have occurred due to chance alone. 
Table 4: Mean percentage knowledge scores in the various age categories: study group, $1^{\text {st }}$ year 2004

\begin{tabular}{|c|c|c|c|c|c|}
\hline Age & Number & $\begin{array}{c}\text { Pre- } \\
\text { test }\end{array}$ & Post 1 & $\begin{array}{c}\text { Difference } \\
\text { pre-post 1 }\end{array}$ & $\begin{array}{c}\text { p-value (pre- } \\
\text { post 1) }\end{array}$ \\
\hline$<\mathbf{2 0}$ & 23 & 26.52 & 63.48 & 36.96 & $<0.0001^{* * *}$ \\
\hline $\mathbf{2 0 - 2 2}$ & 13 & 32.12 & 69.23 & 37.12 & $<0.0001^{* * *}$ \\
\hline $\mathbf{2 3 - 2 5}$ & 1 & 27.50 & 67.50 & 40.00 & $\mathrm{n} / \mathrm{a}$ \\
\hline$>\mathbf{2 5}$ & 6 & 41.25 & 74.58 & 33.33 & $0.0007^{* * *}$ \\
\hline & & & & & \\
\hline
\end{tabular}

Table 5: $\quad$ Mean percentage knowledge scores in the various age categories: study groups, 2005

\begin{tabular}{|c|c|c|c|c|c|c|}
\hline Group & Age & Number & Pre-test & Post 1 & $\begin{array}{l}\text { Difference } \\
\text { pre-post } 1\end{array}$ & $\begin{array}{c}p \text {-value (pre- } \\
\text { post1) }\end{array}$ \\
\hline \multirow{4}{*}{$\begin{array}{c}1^{\text {st }} \text { year } \\
2005\end{array}$} & $<20$ & 19 & 33.94 & 64.34 & 30.39 & $<0.0001^{* k *}$ \\
\hline & $20-22$ & 20 & 35.75 & 71.37 & 35.62 & $<0.0001^{* * *}$ \\
\hline & $23-25$ & 3 & 43.33 & 73.33 & 30.00 & $0.0267^{*}$ \\
\hline & $>25$ & 7 & 48.57 & 71.78 & 23.21 & $0.0076^{* *}$ \\
\hline \multirow{4}{*}{$\begin{array}{l}\text { 3rd year } \\
2005\end{array}$} & $<20$ & 1 & 62.50 & 85.00 & 22.50 & $\mathrm{n} / \mathrm{a}$ \\
\hline & $20-22$ & 20 & 71.87 & 85.87 & 14.00 & $<0.0001^{* * * k}$ \\
\hline & 23-25 & 4 & 65.00 & 83.75 & 18.75 & $0.0287^{*}$ \\
\hline & $>25$ & 12 & 70.83 & 85.20 & 14.37 & $<0.0001^{* * *}$ \\
\hline \multirow{4}{*}{$\begin{array}{l}\text { 4th year } \\
2005\end{array}$} & $<20$ & 1 & 65.00 & 85.00 & 20.00 & $\mathrm{n} / \mathrm{a}$ \\
\hline & $20-22$ & 23 & 69.24 & 83.37 & 14.13 & $<0.0001^{* * *}$ \\
\hline & $23-25$ & 9 & 68.05 & 78.06 & 10.00 & $0.0001^{* k}$ \\
\hline & $>25$ & 10 & 74.50 & 84.50 & 10.00 & $0.0103^{*}$ \\
\hline
\end{tabular}

$* * *$ Statistically very highly significant, paired t-test. $p<0.0001$

** Statistically highly significant, paired t-test. $p<0.01$

* Statistically significant, paired t-test. $p<0.05$

\section{Data}

The mean percentage knowledge scores of the students in the control group (Table 3 ) in the various age categories showed an increase in HIV/ AIDS knowledge scores from pre-test to post-test 2, after they received the intervention. Mean percentage knowledge scores of all the other students in the other groups in the various age categories showed an increase in HIV/AIDS knowledge from pre-test to post-test 1 (Tables 4 and 5).

A regression and correlation analysis was conducted for each group based on the raw pre-test scores and actual ages of the students. Results are summarised in Table 5 a. 
Table 5a: Regression and correlation analysis

\begin{tabular}{|c|c|c|c|c|}
\hline \multicolumn{2}{|c|}{ Group } & $\begin{array}{c}\text { Regression } \\
\text { equation }\end{array}$ & $\begin{array}{c}\text { Pearson } \\
\text { correlation, }\end{array}$ & p-value \\
\hline \multicolumn{2}{|c|}{ Control group } & $?=37.4+5.3 x$ & 0.457 & $<0.001^{* *}$ \\
\hline \multirow{3}{*}{$\begin{array}{l}\text { Study } \\
\text { group }\end{array}$} & 1st year 2004 & $?=22.0+4.7 \mathrm{x}$ & 0.455 & $0.002^{* *}$ \\
\cline { 2 - 5 } & 1st year 2005 & $?=27.9+4.8 \mathrm{x}$ & 0.396 & $0.005^{* *}$ \\
\cline { 2 - 5 } & 3rd year 2005 & $?=71.1-0.2 \mathrm{x}$ & -0.022 & 0.895 \\
\cline { 2 - 5 } & 4th year2005 & $?=63.9+2.3 \mathrm{x}$ & 0.192 & 0.218 \\
\hline
\end{tabular}

$\mathrm{y}=$ Pre-test score

$\mathrm{x}$ = age

** Statistically highly significant, $p<0.01$

\section{Data}

The increasing trend in pre-test scores with age is reflected in the regression equation for all the groups except the third year group where the regression equation showed a downward trend. Three of the five correlation coefficients were statistically significant.

The majority of all the pharmacy students (72\%) analysed were younger than 23 years of age (Tables 4 and 5). From all the different age groups analysed, except in the third year group, students in the older than 25 years category obtained the highest HIV/AIDS knowledge scores at pretest level. An increasing trend in pre-test scores with age is evident in the majority of groups.

comparison of percentage knowledge scores of males and females at pretest, post-test 1 and post-test 2

Table 6: Percentage knowledge scores of males and females: control group

\begin{tabular}{|c|c|c|c|c|c|c|c|}
\hline $\begin{array}{c}\text { Group/G } \\
\text { ender }\end{array}$ & Number & Pre-test & Post 1 & Post 2 & $\begin{array}{c}\text { Difference } \\
\text { pre-post 1 }\end{array}$ & $\begin{array}{c}\text { Difference } \\
\text { pre-post 2 }\end{array}$ & p-value \\
\hline $\begin{array}{c}\text { Control } \\
\text { group }\end{array}$ & & & & & & & $\begin{array}{c}\text { Pre-post } \\
\text { 2 }\end{array}$ \\
\hline Male & 21 & 45.00 & 43.81 & 71.31 & -1.19 & 26.31 & $\begin{array}{c}<0.0001^{*} \\
* *\end{array}$ \\
\hline Female & 31 & 48.06 & 47.98 & 73.23 & -0.08 & 25.17 & $\begin{array}{c}<0.0001^{*} \\
* *\end{array}$ \\
\hline
\end{tabular}

*** Statistically very highly significant, paired t-test. $p<0.0001$ 
Table 7: Percentage knowledge scores of males and females: Study group, $1^{\text {st }}$ year 2004; $1^{\text {st }}, 3^{\text {rd }}$ and $4^{\text {th }}$ year 2005

\begin{tabular}{|c|c|c|c|c|c|c|}
\hline Group & Gender & Number & Pre-test & Post 1 & $\begin{array}{l}\text { Difference } \\
\text { pre-post } 1\end{array}$ & $\begin{array}{c}p \text {-value (pre- } \\
\text { post 1) }\end{array}$ \\
\hline \multirow{2}{*}{$\begin{array}{c}1 \text { st year } \\
2004\end{array}$} & Male & 10 & 31.75 & 69.25 & 37.50 & $<0.0001^{* * *}$ \\
\hline & Female & 34 & 30.96 & 65.51 & 34.56 & $<0.0001^{* * *}$ \\
\hline \multirow{2}{*}{$\begin{array}{c}1^{\text {st }} \text { year } \\
2005\end{array}$} & Male & 22 & 37.84 & 69.09 & 31.25 & $<0.0001^{* * *}$ \\
\hline & Female & 26 & 35.76 & 68.07 & 32.30 & $<0.0001^{* * *}$ \\
\hline \multirow{2}{*}{$\begin{array}{c}\text { 3rd year } \\
2005\end{array}$} & Male & 14 & 69.64 & 83.75 & 14.10 & $<0.0001^{* * *}$ \\
\hline & Female & 22 & 70.34 & 85.79 & 15.45 & $<0.0001^{* * *}$ \\
\hline \multirow{2}{*}{$\begin{array}{l}4^{\text {th }} \text { year } \\
2005\end{array}$} & Male & 8 & 75.31 & 82.81 & 7.50 & .0596 \\
\hline & Female & 36 & 69.02 & 82.56 & 13.54 & $<0.0001^{* * *}$ \\
\hline
\end{tabular}

*** Statistically very highly significant, paired t-test. $p<0.0001$

\section{Data}

Sixty-nine percent of all the pharmacy students surveyed were females. In all the years/groups female percentages exceeded the percentage of males. From all the pharmacy student groups analysed, except for the third year group, males had slightly higher HIV/AIDS knowledge scores than females at pre-test level.

Table 7 also indicates the statistically significant differences in HIV/ AIDS knowledge scores from pre-test to post-test 1 of males and females in the study groups. The mean percentage knowledge scores of the male and female students in the control group showed an increase of 26.31 and 25.17 respectively from pre-test to post-test 2 after they had received the intervention. The mean percentage knowledge scores of all the other male and female students showed increases in HIV/AIDS knowledge from pre-test to post-test 1 which were statistically highly significant except in the case of fourth year males, where it was close to being significant $(p=0.0596)$.

The data were tested for normality as part of statistical analysis with the SAS univariate procedure. Changes in test scores were normally distributed at each test phase in all groups except in the third-year group. In this group, median scores were $72.5 \%$ at pre-test and $87.5 \%$ at posttest 1 , and non-parametric analysis using the Wilcoxon signed rank test confirmed that the median increase of $12.5 \%$ was significant $(p<0.0001)$. 
4.4 Overall comparison of percentage knowledge scores of students at pre-test, post test 1 and post-test 2

\begin{tabular}{|c|c|c|c|c|c|c|}
\hline Assessment & Number & Mean & Std Dev & Min & Max & $\boldsymbol{p}$-value \\
\hline Pre & 53 & 46.60 & 11.01 & 17.50 & 75.00 & \\
\hline Post 1 & 53 & 46.13 & 12.67 & 10.00 & 75.00 & \\
\hline Post 2 & 53 & 72.41 & 7.21 & 55.00 & 92.50 & \\
\hline $\begin{array}{c}\text { Change from Pre to } \\
\text { Post 1 }\end{array}$ & 53 & -0.47 & 7.27 & -15.00 & 17.50 & 0.6388 \\
\hline $\begin{array}{c}\text { Change from Pre to } \\
\text { Post 2 }\end{array}$ & 53 & 25.81 & 12.60 & 2.50 & 57.50 & $\begin{array}{c}<0.0001 \\
* * *\end{array}$ \\
\hline
\end{tabular}

Table 8: Overall percentage knowledge scores of students: control group

$\star \star \star$ Statistically very highly significant, paired t-test. $p<0.0001$

\begin{tabular}{|c|c|c|c|c|c|c|c|}
\hline Group & Assessment & Number & Mean & Std Dev & Min & $\operatorname{Max}$ & $p$-value \\
\hline \multirow{3}{*}{$\begin{array}{c}1^{\text {st }} \text { year } \\
2004\end{array}$} & Pre & 46 & 31.47 & 11.42 & 12.50 & 62.50 & \\
\hline & Post 1 & 46 & 66.47 & 10.24 & 45.00 & 90.00 & \\
\hline & $\begin{array}{l}\text { Change from } \\
\text { pre to post } 1\end{array}$ & 46 & 35.00 & 11.24 & -7.50 & 55.00 & $\underset{x<* x}{<0.0001}$ \\
\hline \multirow{3}{*}{$\begin{array}{l}1^{\text {st }} \text { year } \\
2005\end{array}$} & Pre & 51 & 37.50 & 12.17 & 15.00 & 72.50 & \\
\hline & Post 1 & 51 & 68.87 & 9.63 & 45.00 & 90.00 & \\
\hline & $\begin{array}{l}\text { Change from } \\
\text { pre to post } 1\end{array}$ & 51 & 31.37 & 9.82 & 0.00 & 57.50 & $\underset{* * * k}{0.0001}$ \\
\hline \multirow{3}{*}{$\begin{array}{c}3^{\text {rd }} \text { year } \\
2005\end{array}$} & Pre & 38 & 70.52 & 9.00 & 47.50 & 87.50 & \\
\hline & Post 1 & 38 & 85.13 & 6.01 & 70.00 & 95.00 & \\
\hline & $\begin{array}{l}\text { Change from } \\
\text { pre to post } 1\end{array}$ & 38 & 14.60 & 10.91 & -7.50 & 45.00 & $\underset{x *-x \cdot k}{0.0001}$ \\
\hline \multirow{3}{*}{$\begin{array}{l}4^{\text {th }} \text { year } \\
2005\end{array}$} & Pre & 45 & 70.50 & 10.60 & 45.00 & 95.00 & \\
\hline & Post 1 & 45 & 82.50 & 8.90 & 60.00 & 97.50 & \\
\hline & $\begin{array}{l}\text { Change from } \\
\text { pre to post } 1\end{array}$ & 45 & 12.00 & 8.68 & -7.50 & 30.00 & $<\underset{* \star * \star}{<.001}$ \\
\hline
\end{tabular}

Table 9: Overall percentage knowledge scores of students: study groups 2004 and 2005

*** Statistically very highly significant, paired t-test. $p<0.0001$

\section{Data}

The percentage knowledge scores of all the groups of students were compared at pre-test, post-test 1 , and post-test 2 where applicable, to determine the change in scores. Tables 8 and 9 illustrate the differences in mean scores for the groups of students from pre-test to post-test 1 and post-test 2. A statistical significant difference $(p=0.0001)$ was indicated in HIV/AIDS knowledge scores from pre-test to post-test 1 and for the control group from pre-test to post-test 2 . 
The knowledge of both the first year pharmacy student groups (2004 and 2005) increased after the intervention to almost the pre-intervention level $( \pm 70 \%)$ of the third and fourth year groups. Both these first year pharmacy student groups achieved a greater than 30\% actual knowledge gain (off a low baseline $<40 \%$ ).

\subsection{Achievement levels of all the students before and after the intervention}

For this comparison, an achievement level mark of $60 \%$ was used. Sixty percent indicates a level of sufficient basic HIV/AIDS knowledge, which would offer some confidence in the ability of the learner to respond to patients. Pharmacy students' knowledge was considered adequate if $60 \%$ or more of the students responded with the correct response. Table 10 illustrates the major improvements from pre-test to post-test 1 .

\section{Table10: Percentage of students who achieved a knowledge score} of $=60 \%$

\begin{tabular}{|c|c|c|c|c|c|c|}
\hline Group & Number & $\begin{array}{c}\% \text { Passed at } \\
\text { pre-test }\end{array}$ & $\begin{array}{l}\% \text { Passed at } \\
\text { post-test } 1\end{array}$ & $\begin{array}{c}P \text { value } \\
\text { (post-test } \\
1 \text { vs pre- } \\
\text { test) }\end{array}$ & $\begin{array}{l}\% \text { Passed at } \\
\text { post- test } 2\end{array}$ & $\begin{array}{c}P \text { value } \\
\text { (post-test } 2 \\
\text { vs pre-test) }\end{array}$ \\
\hline Control group & 53 & $11.3(6 / 53)$ & $17.0(9 / 53)$ & 0.403 & $\begin{array}{c}96.2 \\
(51 / 53)\end{array}$ & $\underset{* * * *}{<0.001}$ \\
\hline \multicolumn{7}{|l|}{ Study groups } \\
\hline 1st year 2004 & 46 & $\begin{array}{c}2.2 \\
(1 / 46)\end{array}$ & $\begin{array}{c}80.4 \\
(37 / 46)\end{array}$ & $\underset{* * * *}{<0.001}$ & $\mathrm{n} / \mathrm{a}$ & $\mathrm{n} / \mathrm{a}$ \\
\hline 1st year 2005 & 51 & $3.9(2 / 51)$ & $\begin{array}{c}86.3 \\
(44 / 51)\end{array}$ & $\underset{* * * *}{<0.001}$ & $\mathrm{n} / \mathrm{a}$ & $\mathrm{n} / \mathrm{a}$ \\
\hline 3rd year 2005 & 38 & $86.8(33 / 38)$ & $\begin{array}{c}100.0 \\
(38 / 38)\end{array}$ & 0.054 & $\mathrm{n} / \mathrm{a}$ & $\mathrm{n} / \mathrm{a}$ \\
\hline 4th year 2005 & 45 & $91.1(41 / 45)$ & $\begin{array}{c}100.0 \\
(45 / 45)\end{array}$ & 0.117 & $\mathrm{n} / \mathrm{a}$ & $\mathrm{n} / \mathrm{a}$ \\
\hline
\end{tabular}

\section{Data}

A very low percentage of first year students, two percent in 2004 and four percent in 2005, obtained the achievement level mark of $60 \%$ at pretest level. It is evident that these students had little or no exposure to HIV/AIDS information previously. After the teaching intervention the first year students' achievement level marks increased to $80 \%$ and $86 \%$ respectively.

High percentages (87\% and $91 \%$ ) of third and fourth year students respectively obtained the achievement level mark of $60 \%$ at pre-test and $100 \%$ of the students obtained the achievement level mark of $60 \%$ at post-test 1 . The high percentage at pre-test level shows that senior pharmacy students have been exposed to HIV/AIDS information and that they increased their knowledge even further after the intervention.

The mean HIV/AIDS knowledge scores of the control group and the various groups of pharmacy students were compared. The level of HIV/ AIDS knowledge of the pharmacy students increased significantly after 
completion of the teaching intervention while HIV/AIDS knowledge of the control group also increased after they received the teaching intervention. The increase in HIV/AIDS knowledge scores indicates the positive effect of the teaching intervention.

\section{Discussion and Conclusion}

\subsection{Discussion of results}

To assess HIV/AIDS knowledge, undergraduate pharmacy students completed an HIV/AIDS Knowledge Questionnaire. The HIV/AIDS Knowledge Questionnaire consisted of statements covering different HIV/ AIDS topics.

When the baseline (pre-test) HIV/AIDS knowledge of students from the control group and the pharmacy student groups in their respective age categories was analysed, it was found that students in the older than 25 years category obtained higher HIV/AIDS knowledge scores. An increasing trend in HIV/AIDS knowledge pre-test scores with age was observed (Tables 3 to 5). In addition, Tables 3 to 5 illustrate that the mean percentage HIV/AIDS knowledge scores of students from the control group and the different pharmacy student groups, in the various age categories, increased after they received the teaching intervention.

Sixty nine percent of all the pharmacy students who participated in this study were females. In all the years/groups female percentages exceeded the percentage of males. From all the pharmacy student groups analysed, except for the third year group, males obtained slightly higher HIV/AIDS knowledge scores than females at baseline level (Tables 6 and 7). Data from a previous study to analyse the levels of knowledge about HIV/AIDS prevention in 23 developing countries found that levels of knowledge are almost always higher among men than among women (WHO, 2003). Also, a study conducted by $\mathrm{Li}$ and colleagues (2004) to assess the overall AIDS knowledge among students in China revealed a significant gender difference in AIDS knowledge, with males being more knowledgeable than females (Li, 2004).

Tables 6 and 7 also illustrate that the mean percentage HIV/AIDS knowledge scores of all the male and female students increased after they received the teaching intervention. Table 9 illustrated that if pharmacy students receive the teaching intervention early in their first year, their HIV/AIDS knowledge immediately increases to the baseline HIV/AIDS knowledge level of the third and fourth year students.

In Table 10, at baseline level, only two percent of first year students in 2004 and three percent of first year students in 2005 obtained the achievement level mark. The results at baseline level indicated that HIV/AIDS knowledge was inadequate. After the teaching intervention the first year students' achievement level marks increased to $80 \%$ and $86 \%$ respectively.

The high percentage (91\%) of third and fourth year students who obtained the achievement level mark at baseline level indicates that senior pharmacy students have been exposed to HIV/AIDS information. They increased their knowledge even further after the intervention. 


\subsection{Conclusion}

HIV/AIDS knowledge is one of the fundamental requirements for pharmacists to be able to perform their role in the management of HIV.

The null hypothesis investigated by this study stated "The knowledge of pharmacy students from the University of Limpopo (Medunsa Campus)/ Tshwane University of Technology Schools of Pharmacy regarding HIV infection and AIDS will not improve after a teaching intervention".

Two-sample t-tests were performed on the data to test the null hypothesis by comparing the mean differences of the control group with the mean differences of the study groups before and after the teaching intervention. Statistically very highly significant differences with probability values $<0.0001$ were detected.

The null hypothesis was therefore rejected by this study.

In South Africa, with its diverse cultures, HIV/AIDS education programmes should be developed within the context of the specific cultural beliefs and values of the target groups. Such programmes will help to eliminate myths and misconceptions about HIV/AIDS. Health educators should invite young people/students to help plan, implement and evaluate HIV/AIDS programmes. ${ }^{1}$

Educators and peers should be trained to provide an effective HIV/AIDS education programme, as effective programmes offer accurate information.

HIV/AIDS education programmes should encompass both knowledge and skills.

HIV is spread mainly by behaviours - sexual and drug taking - that are generally private, sometimes illegal, and often difficult to discuss openly. But they are the engines driving the epidemic. When it became apparent that people were not going to change their sexual behaviour merely because they were told they should, UNICEF rallied around the idea of teaching life skills as part of HIV/AIDS education, as this approach will allow people to act upon their knowledge. The assumption is that people are lacking in certain skills (for example, assertiveness, decisionmaking, refusal and negotiating skills), which, if taught and learned, they would be able to apply in different situations, thereby reducing their risk of HIV infection.

\section{References}

American Society of Hospital Pharmacists. 1993. ASHP Statement on Pharmaceutical Care. American Journal of Hospital Pharmacy, 50: $1720-3$.

1. A CD-based teaching programme "The pharmacist in HIV/AIDS" from the School of Pharmacy, University of Limpopo (Medunsa Campus) is now implemented in the curricula of undergraduate pharmacy students in addition to being incorporated as part of the Continuing Professional Development (CPD) activities of the South African Pharmacy Council. For more information about this course contact Nikki Williamson at: Tel: 0125214240 or postgrad2@ul.ac.za. 
Bhatnagar, M. \& Bhalwar,C. 2005. The curse of HIV: How well prepared is our paramedical force? MJAFI, 61: 230.

Blumenthal, W., Springer, K., Jones, T. \& Sterk, C. 2002. Pharmacy student knowledge, attitudes and beliefs about syringes to injection drug users. Journal of American Pharmaceutical Association, 42: S34-9. Abstract available from www.ncbi.nlm.nih.gov

Cantwell-Mcnelis, K. \& James, C. 2002. Role of clinical pharmacists in outpatient HIV clinics. Am J Health-Syst Pharm, 59(5): 447-452.

Coates,T; Richter,L. \& Caceres, C. 2008. Behavioural strategies to reduce HIV transmission: how to make them work better. Available online from www.thelancet.com/journals/lancet/article/PIIS01406736(08)60886-7/fulltext - 28k - Date accessed 23-01-09

Cornelissen, M. 2005. HIV/AIDS knowledge, awareness and perception of undergraduate students at the University of Stellenbosch. Assignment presented in partial fulfilment for the degree of Master of Philosophy at Stellenbosch University.

Dijkstra, A; Kangawaza, E; Martens, C; Boer, H. \& Rasker, J. 2007. K knowledge about HIV/AIDS and policy knowledge in a South African state hospital, Journal of Social Aspects of HIV/AIDS, 4(2): 636.

Fisher, A. \& Foreit, J. 2002. Designing HIV/AIDS intervention studies. An Operations Research Handbook. Population Council.

Hardy, A. 1990. National Health Interview Survey Data on adult knowledge of AIDS in the United States. Public Health Reports, 105: 629634. Abstract available from http://www.pubmedcentral.nih.gov/ articlerender - Date accessed 17-04-08

Harrison, A., Smit, J. \& Myer, L. 2000. Prevention of HIV/AIDS in South Africa: a review of behaviour change interventions, evidence and options for the future. Journal of Science, 96(6): 285.

Letamo, G. 2004. HIV/AIDS-related stigma and discrimination among adolescents in Botswana. African population Studies, 19(2): 191204.

Li, X., Lin, C., Gao, Z., Stanton, B., Fang, X., Yin, Q. \& Wu, Y. 2004. HIV/ AIDS knowledge and the implications for health promotion programmes among Chinese college students: geographic, gender and age differences. Health Promotion International, 19(3): 345. Available from www.heapro.oxfordjournals.org - Date accessed 1704-08

Myers, T., Cockerill, R., Worthington, C., Millson, M. \& Rankin, J. 1998. Community pharmacists perspectives on HIV/AIDS and interventions for injection drug users in Canada. AIDS Care, 10(6): 689.

Prasad, R. 2001. Development of the HIV/AIDS Q-Sort Instrument to measure physician attitudes. Family Medicine, 33(10): 772. Available from www.stfm.org/fmhub/fm2001/nov01/cram.pdf Date accessed 18-04-08

Rissi, M; Machado, A. \& Figueiredo, M. 2005. Health care workers and 
AIDS: a differential study of beliefs and affects associated with accidental exposure to blood. Cad. Saude Publica, 21(1):283.

Santis, W; Whitman, C; Venkatapuram, S; Rosenblum, M; Rosati, M. \& Palakurti, P. 2003. HIV/AIDS and employment: Protecting young people and involving them in work-related solutions. Available from www.hhd.org/documents/hyderabad.pdf - Date accessed 18-04-08

School of Pharmacy. University of Limpopo. 2003. The pharmacist and HIV / AIDS.

Sheridan, J., Bates, I., Webb, D. \& Barber, N. 1994. Educational intervention in pharmacy student's attitudes to HIV/AIDS and drug misuse. Med Educ, 28(6): 492-500.

Umeh, C; Essien, J; Ezedinachi, E. \& Ross, M. 2008. Knowledge, Beliefs and Attitudes about HIV/AIDS related issues, and the Sources of Knowledge among Health Care Professionals in Southern Nigeria. J R Soc Health, 128(5):233. www.pubmedcentral.nih.gov/ picrender.fcgi? artid $=2562902 \& b l o b t y p e=p d f-$ Date accessed 2701-09

Van der Walt, E. 2003. Defining and implementing an appropriate role for pharmacists in HIV/AIDS management in South Africa. PhD Thesis. MEDUNSA.

WHO. 1993. How to investigate drug use in health facilities. Geneva.

\section{APPENDIX 1:}

\section{HIV/AIDS KNOWLEDGE QUESTIONNAIRE}

(Pre/Post-intervention questionnaire)

Please complete the following:

Date:

Year of study:

Student nr:

Age:

Gender:

(Please mark one)

(Please mark one)

Please indicate your answer by an $\mathrm{X}$ in the appropriate box

\begin{tabular}{|l|l|l|l|l|}
\hline$<20$ & & & $M$ & \\
\hline $20-22$ & & & $F$ & \\
\hline $23-25$ & & & & \\
\hline$>25$ & & & & \\
\hline
\end{tabular}




\begin{tabular}{|c|c|c|c|}
\hline & QUESTION & TRUE & FALSE \\
\hline 1 & HIV and AIDS are one and the same thing & & $\mathbf{X}$ \\
\hline 2 & CD4+ T-1ymphocytes are the major cellular targets for HIV & $\mathbf{X}$ & \\
\hline 3 & HIV can be transmitted through breast milk & $\mathbf{X}$ & \\
\hline 4 & HIV can be contracted by donating blood & & $\mathbf{X}$ \\
\hline 5 & $\begin{array}{l}\text { HIV-1 Subtype C predominates among the heterosexual } \\
\text { population in South Africa }\end{array}$ & $\mathbf{X}$ & \\
\hline 6 & Reverse transcriptase is an important enzyme in retroviruses & $\mathbf{X}$ & \\
\hline 7 & NRTI's inhibit the transcription of viral RNA into DNA & $\mathbf{X}$ & \\
\hline 8 & The ELISA test detects antibodies to HIV & $\mathbf{X}$ & \\
\hline 9 & $\begin{array}{l}\text { The "window period" is the period between infection and the } \\
\text { development of AIDS }\end{array}$ & & $\mathbf{X}$ \\
\hline 10 & A negative test result exclude the possibility of an infection & & $\mathbf{X}$ \\
\hline 11 & A positive result does not have to be confirmed & & $\mathbf{X}$ \\
\hline 12 & $\begin{array}{l}\text { Post test counselling does not have to take place if a patient is } \\
\text { negative }\end{array}$ & & $\mathbf{X}$ \\
\hline 13 & Failure to thrive is indicative of possible HIV infection in children & $\mathbf{X}$ & \\
\hline 14 & $\begin{array}{l}\text { Nevirapine monotherapy is recommended to reduce vertical } \\
\text { transmission }\end{array}$ & $\mathbf{x}$ & \\
\hline 15 & All babies born to HIV infected women are infected with HIV & & $\mathbf{X}$ \\
\hline 16 & $\begin{array}{l}\text { Candidiasis is one of the most frequent fungal infections seen in } \\
\text { HIV }\end{array}$ & $\mathbf{X}$ & \\
\hline 17 & $\begin{array}{l}\text { TB is the leading cause of HIV-associated opportunistic } \\
\text { infections in developing countries }\end{array}$ & $\mathbf{X}$ & \\
\hline 18 & Primaquine is used for TB prophylaxis & & $\mathbf{x}$ \\
\hline 19 & Oral thrush can lead to serious wasting & $\mathbf{X}$ & \\
\hline 20 & Typhoid vaccine should be given to HIV positive patients & & $\mathbf{x}$ \\
\hline 21 & Zidovudine and zalcitabine are classified as NRTI's & $\mathbf{X}$ & \\
\hline 22 & The most common side effect of nevirapine is skin rash & $\mathbf{X}$ & \\
\hline 23 & $\begin{array}{l}\text { Patients with CD4 counts below 2000cells } / \mathrm{mm} 3 \text { should be } \\
\text { offered ART }\end{array}$ & & $\mathbf{X}$ \\
\hline 24 & HAART will eliminate the HI virus from the body & & $\mathbf{X}$ \\
\hline 25 & The viral load test is used to monitor drug therapy & $\mathbf{X}$ & \\
\hline 26 & $\begin{array}{l}\text { Two NRTI's together with a PI or a NNRTI is an effective triple } \\
\text { drug regimen }\end{array}$ & $\mathbf{X}$ & \\
\hline 27 & $\begin{array}{l}\text { A patient needs to comply only } 80 \% \text { to the treatment regimen to } \\
\text { obtain maximal results }\end{array}$ & & $\mathbf{X}$ \\
\hline 28 & $\begin{array}{l}\text { When the patient viral load is undetectable, the antibody test will } \\
\text { be negative }\end{array}$ & & $\mathbf{x}$ \\
\hline 29 & PEP is best within 1-2 hours & $\mathbf{X}$ & \\
\hline 30 & PEP will eliminate the risk of viral transmission & & $\mathbf{X}$ \\
\hline 31 & The viral burden is high during seroconversion & $\mathbf{X}$ & \\
\hline 32 & The exposed person should be tested immediately & $\mathbf{X}$ & \\
\hline
\end{tabular}

